\title{
Perkembangan Sister City Surabaya-Guangzhou dan Dampaknya terhadap Kota Surabaya
}

\author{
Luluk Erika dan Rizki Rahmadini Nurika \\ UIN Sunan Ampel Surabaya
}

\begin{abstract}
ABSTRAK
Sister city adalah konsep yang mengacu pada kerjasama yang dilakukan oleh dua kota yang berasal dari dua negara yang berbeda. Surabaya adalah salah satu kota di Indonesia yang aktif membentuk inisiasi sister city, salah satunya dengan kota Guangzhou, Tiongkok. Namun, program sister city Surabaya-Guangzhou seakan tampak "tenggelam” oleh keberadaan sister city Surabaya dengan kota-kota lain seperti Busan, Korea Selatan; dan Kitakyushu, Jepang. Atas latar belakang tersebut, penelitian ini berusaha untuk mengungkap bagaimana perkembangan sister city SurabayaGuangzhou dan seperti apa dampaknya bagi kota Surabaya. Penelitian ini menggunakan konsep sister city dan model efektivitas rezim Arild Underdal untuk menjawab rumusan masalah penelitian. Metode penelitian yang digunakan adalah kualitatif-deskriptif dengan teknik pengumpulan data berupa wawancara dan studi pustaka. Hasil temuan menunjukkan bahwa sister city Surabaya-Guangzhou berjalan dengan kurang efektif jika dinilai dari level of collaboration, problem malignancy, dan problem solving. Meskipun demikian, inisiasi sister city tersebut masih tetap memberikan sejumlah kontribusi terhadap kemajuan kota Surabaya.
\end{abstract}

Kata-kata Kunci: Sister City, Surabaya, Guangzhou, Pemerintah Daerah, Model Efektivitas Rezim

Sister city is a concept which refer to a cooperative initiative set up between two cities from two different country of origin. Surabaya is one of well-known cities in Indonesia which actively engage in such programs, among them are cooperation with Guangzhou, China; Busan, South Korea; and Kitayushu, Japan. However, a focus on sister city initiatives between Surabaya and Guangzhou seems to be relatively understudied. This research is aimed to uncover the dynamics of Surabaya-Guangzhou sister city initiative and how is it impacting Surabaya specifically. To explain this, the author put some emphasis on the concept "sister city" and employing Arild Underdal's Regime Effectivity Model. a qualitativedescriptive research method is undergone with data gatehered through literature studies, as well as direct interview. This research found that the initiative has resulted in relatively ineffective outvomes under the indicator of level of collaboration, problem malignancy, and problem solving. Nevertheless, the sister city between the two cities has given a number of contributions to the growth of Surabaya.

Keywords: Sister City, Surabaya, Guangzhou, Regional Government, Model of Regime Effectiveness 
Kerja sama sister city telah sering dilakukan oleh beberapa kota di Indonesia, termasuk halnya kota Surabaya. Surabaya merupakan kota terbesar kedua di Indonesia setelah Jakarta dengan luas wilayah 33.306,30 Ha (Pemerintah Surabaya t.ta). Surabaya dikenal sebagai ibukota provinsi Jawa Timur dan juga pusat bisnis, dan pendidikan di Indonesia bagian timur. Tidak hanya itu, Surabaya bahkan disebut juga sebagai kota industri maju dengan posisinya sebagai pintu gerbang perdagangan utama di Indonesia bagian timur (East Java t.t). Hal-hal tersebut lantas menunjukan sejumlah potensi yang dimiliki oleh kota Surabaya.

Dalam rangka mengembangkan potensi perdagangan, pemerintah kota Surabaya menjalin kerja sama sister city dengan kota di Tiongkok selaku negara dengan intensitas perdagangan yang relatif bertumbuh dengan pesat. Salah satu program kemitraaan Sister City Surabaya yakni dengan Guangzhou, salah satu kota di bagian selatan Tiongkok. Kesamaan antara kota Surabaya dengan kota Guangzhou yang merupakan kota pelabuhan dan kota perdagangan menjadi konsiderasi utama Pemerintah kota Surabaya menjalin kerja sama sister city. Hal ini lantas diinisiasikan dengan tujuan untuk beberapa hal. Pertama, menyiapkan kota Surabaya dalam menghadapi arus globalisasi dan pasar bebas. Kedua, dapat membantu usaha pembangunan kota Surabaya. Ketiga, dapat mempromosikan kota Surabaya ke ranah dunia internasional (Pemerintah Kota Surabaya t.tb).

Namun, kajian terhadap kerjasama ini relatif minim dan acapkali tetutupi dengan adanya inisiasi-inisiasi sister city Surabaya dengan kota-kota lain, seperti Busan, Korea Selatan; dan Kitakyushu, Jepang. Atas latar belakang tersebut, penelitian ini berusaha untuk mengungkap bagaimana perkembangan sister city SurabayaGuangzhou dan seperti apa dampaknya bagi kota Surabaya. Penelitian ini menggunakan konsep sister city dan model efektivitas rezim Arild Underdal untuk menjawab rumusan masalah penelitian. Metode penelitian yang digunakan adalah kualitatif-deskriptif dengan teknik pengumpulan data berupa wawancara dan studi pustaka. Hasil temuan menunjukkan bahwa Sister City SurabayaGuangzhou berjalan dengan kurang efektif jika dinilai dari level of collaboration, problem malignancy, dan problem solving. Meskipun demikian, inisiasi sister city tersebut masih tetap memberikan sejumlah kontribusi terhadap kemajuan kota Surabaya. 


\section{Merangkai Posisi Surabaya dan Guangzhou dalam Diskursus "Sister City"}

\section{Konseptualisasi “Sister City”}

Istilah sister city itu sendiri sejatinya diperkenalkan pertama kali oleh Presiden Amerika Serikat yaitu Dwight D. Eisenhower tahun 1956 pada konferensi Gedung Putih sebagai konsep yang mengacu pada peningkatan diplomasi antar masyarakat yang akhirnya tidak hanya ekslusif di tingkat nasional saja, namun berkembang menjadi tingkat kota hingga provinsi (Sister-city t.t). Penerapan kerja sama sister city pertama kali terjadi di Benua Eropa, yaitu Keighley, Yorkshire Barat-sekarang berada di Inggris-dengan Poix-dunord, Perancis pada tahun 1920 (Salam 2004). Istilah sister city kemudian merujuk pada kerja sama antar kota yang mana segala sesuatu merujuk pada hak dan kewenangan setingkat kota (Oetomo 2004).

Secara lebih terperinci, sister city Internasional mendefinisikan sister city sebagai hubungan kerja sama yang terjadi dalam jangka panjang antara dua kota dari dua negara yang berbeda melalui bidang budaya, pendidikan, bisnis, dan teknis yang diformalkan dalam Memorandum of Understanding (MoU) dan ditandatangani oleh walikota dua kota dari dua negara tesebut (Sister-city t.t). Berkembangnya sister city dilatarbelakangi oleh semakin berkembangnya isu-isu multilateral dalam berbagai bidang seperti ekonomi, budaya, sosial, dan teknologi yang dianggap dapat memberikan pengaruh secara tidak langsung. Termasuk dalam hal ini adalah munculnya aktor-aktor baru dalam hubungan internasional seperti aktor sub negara, yaitu pemerintah provinsi dan/atau pemerintah kota sister city dinilai akan dapat membangun hubungan yang aktif dalam meningkatkan intensitas kerja sama dan saling memahami keberagaman budaya, lingkungan, dan sosial antar kedua wilayah (Kolinggoru 2018).

Tujuan adanya kerja sama sister city adalah dapat menghasilkan kreativitas antar kedua wilayah untuk bekerja sama dalam menyelesaikan masalah melalui pertukaran pada aspek pendidikan, bisnis, budaya serta dapat mengembangkan perekonomian antar wilayah (Oklahima Secretary of State t.t). Manfaat spesifik dari kerja sama sister city yakni: a) memperkuat kerja sama antar kota-kota di berbagai dunia; b) memberikan kesempatan kepada pejabat kota mapun masyarakat untuk merasakan dan menjelajahi kebudayaan lain dalam kerja sama masyarakat jangka panjang; c) menciptakan 
keadaan yang bertujuan untuk mengembangkan ekonomi dan masyarakat yang terimplementasi dan kuat; d) membuat lingkungan yang mendorong keaktifan masyarakatnya untuk berusaha belajar, bekerja dan menyelesaikan masalah secara bersama dengan kreatif dalam sebuah hubungan timbal balik budaya, pendidikan, bisnis, profesi, perkotaan, dan pertukaran secara teknik dalam proyekproyek tertentu; e) mengkolaborasikan organisasi-organisasi kemasyarakatan antar dua kota yang mempunyai tujuan yang sama (Sister-city t.t).

Terdapat beberapa faktor yang membuat suatu kota melakukan kerja sama luar negeri. Menurut Clarke (2011), kerja sama sister city terjadi dilatarbelakangi oleh hubungan sejarah yang ingin dipertahankan dan/atau dipicu dengan adanya keprihatinan terhadap situasi kontemporer dan keinginan untuk memecahkannya secara bersama, baik masalah budaya, ekonomi, maupun ideologi. Selain itu, adanya kesamaan persamaan masalah dan kondisi dalam hal perdagangan dan pendidikan dapat pula turut mendorong diinisiasikannya suatu kerja sama sister city. Begitu pula halnya dengan adanya rasa kemanfaatan dalam bidang kebudayaan (Oetomo 2004).

\section{Sister City Surabaya-Guangzhou}

Kerja sama sister city antara pemerintah kota Surabaya dengan kota Guangzhou dimulai dari penandatanganan Letter of Intent (LoI) oleh Walikota Surabaya pada saat itu, Bambang Dwi Hartono, dengan Walikota Guangzhou yakni Zhang Guangning pada tanggal 2 September 2003. Inisiasi ini pun ditindaklanjuti dalam bentuk kerjasama yang lebih dalam dan dimanifesatasikan dengan adanya penandatanganan Memorandum of Understanding (MoU) pada 21 Desember 2005. Bidang-bidang kerja sama yang disepakati, antara lain: pertukaran tata cara manajemen perkotaan, promosi usaha, perdagangan dan pariwisata, kebudayaan, kesenian, pendidikan, pemuda dan olahraga (MoU Sister City Surabaya-Guangzhou 2003).

Namun, hingga tahun 2019, realisasi kerja sama Sister City Surabaya-Guangzhou tampak kurang sesuai dengan apa yang tertulis dalam kesepakatan awal kedua belah pihak. Pasalnya, jika dibandingkan dengan kerja sama Sister City Surabaya-Xiamen (kota lain di China), implementasi dari Sister City SurabayaGuangzhou lebih sedikit (Ariana 2016). Semua bidang kerja sama Sister City Surabaya-Xiamen berjalan secara berkelanjutan dengan 
adanya sejumlah realisasi nyata dalam bentuk program-program, sedangkan untuk Sister City Surabaya-Guangzhou tidak semua bidang kerja sama terrealisasi. Bahkan, di bawah kepemimpinan Walikota Surabaya Tri Rismaharini, realisasi kerja sama sister city Surabaya lebih cenderung berfokus pada inisasi-inisasi dari kota lain, seperti sister city Surabaya-Kitakyushu (kota di Jepang) dan Sister City Surabaya-Busan (kota di Korea Selatan) (Kartika 2019).

Beberapa penelitian terkait sister city Surabaya telah dilakukan sebelumnya.Pertama, penelitian Rizky Pradipta Sauwir dalam skripsi yang berjudul "Efektivitas Implementasi Pemerintah Surabaya Melaksanakan Kerja sama Sister City dengan Busan (2007-2012) di bidang pendidikan". Hasil penelitian Rizky menunjukkan bahwa kerja sama sister city Surabaya dengan Busan di bidang pendidikan direalisasikan dengan cara pertukaran pelajar tingkat Sekolah Dasar (SD), Sekolah Menengah Pertama (SMP), Sekolah Menengah Atas (SMA), dan Perguruan Tinggi (Universitas). Tidak hanya berfokus pada peningkatan kualitas objek pembelajaran semata, terdapat pula sejumlah program yang ditujukan untuk meningkatkan mutu tenaga pengajar. Program pertukaran tim pengajar, guru dan dosen yang telah dilakukan juga dinilai telah berjalan efektif dan sesuai dengan tujuan kesepakatan dalam MoU, serta mengguntungkan kedua kota (Sauwir 2013).

Kedua, penelitian Rio Rakhmat Bramantio dalam skripsi yang berjudul "Efektivitas Kerja sama Sister City Surabaya dengan Busan dan Surabaya dengan Kochi Dalam Bidang Pendidikan". Hasil penelitian Rio menunjukkan bahwa kerja sama sister city Surabaya dengan Busan dalam bidang pendidikan hanya terbatas pada pelaksanaan program dan belum sepenuhnya memenuhi target kesepakatan awal. Hasil yang cukup berbeda terjadi dengan kerjasama dengan Kochi. Kerja sama sister city Surabaya dengan Kochi dalam bidang pendidikan telah sampai pada pelaksanaan hingga memberikan hasil bagi masyarakat kota Surabaya sesuai dengan tujuan dalam kesepakatanMoU (Bramantio 2008).

Ketiga, penelitian Dina Ariana dalam skripsi yang berjudul "Keuntungan Kerja sama Sister City Antara Kota Surabaya Dengan Xiamen Tiongkok". Hasil penelitian Dina menunjukkan bahwa kerja sama sister city Surabaya dengan Xiamen membawa dampak positif dan memberikan keuntungan bagi masing-masing kota. Keuntungan ini dilihat dari berbagai bidang kerja sama yang disepakati dalam MoU awal. Beberapa di antaranya adalah 
ekonomi, perdagangan, IPTEK, pendidikan, olahraga dan budaya, dan kesehatan (Ariana 2016).

Keempat, penelitian Irdayanti dalam jurnal yang berjudul "Substansi Kerja sama Luar Negeri Sister City Kota Surabaya - Xiamen" tahun 2014. Hasil penelitian Irdayanti menunjukkan bahwa kota Surabaya dan Xiamen memulai kerja sama pada bidang pendidikan, ekonomi, perdagangan, kebudayaan, dan pariwisata. Realisasi kerja sama sister city Surabaya dengan Xiamen berjalan dengan efektif sesuai dengan MoU yang disepakati. Sejumlah program dan kegiatan telah diimplentasikan yang memberikan hasil berupa peningkatan kapasitas, serta pengembangan potensi kota dan teknologi di Kota Surabaya (Irdiyanti 2014).

Dari beberapa penelitian terdahulu tersebut, tampak bahwa kebanyakan peneliti sebelumnya memilih untuk meneliti kerja sama sister city Surabaya dengan sejumlah kota yang dianggap menunjukkan hasil signifikan. Sementara itu, kerja sama sister city Surabaya dengan Guangzhou yang hasilnya kurang signifikan dan relatif tidak terlihat belum mendapat sorotan akademis yang mumpuni untuk mengetahui apa yang sebenarnya terjadi dengan kerja sama sister city tersebut. Dengan demikian, maka penelitian ini bermaksud untuk memberikan kontribusi tersendiri dalam perkembangan diskursus inisiasi-inisiasi sister city di kota-kota di Indonesia-terkhusus di Surabaya-dengan memberikan penjelasan mengenai bagaimana perkembangan Sister City SurabayaGuangzhou dan seperti apa dampaknya bagi kota Surabaya.

\section{Kerangka Analisis dalam Mengaji Perkembangan Sister City Surabaya-Guangzhou}

\section{Kualitatif Deskriptif sebagai Dasar Metodologi}

Dalam penelitian ini, peneliti menggunakan metode kualitatif deskriptif. Sebagaimana yang dijelaskan Sukmadinata, penelitian kualitatif adalah suatu penelitian yang ditujukan untuk mendeskripsikan atau menganalisis fenomena, peristiwa, sikap, kepercayaan, persepsi, aktivitas sosial, dan pemikiran orang secara individual maupun kelompok (Sukmadinata 2011). Tujuan dari penelitian kualitatif adalah untuk memperoleh suatu gambaran sepenuhnya mengenai suatu hal menurut persepsi manusia yang diteliti (Sulistyo 2006). Penelitian kualitatif bersifat dinamis yakni terbuka terhadap perubahan, penambahan maupun penggantian 
selama proses analisisnya (Srivastiva \& Thomson 2009). Fokus dalam penelitian kualitatif adalah elemen manusia, obyek, institusi, dan interaksi antar elemen-elemen tersebut dalam memahami suatu fenomena (Majid \& N 2010).Dengan demikian penelitian kualitatif dapat dikatakan diorientasikan untuk mendapatkan perspektif secara mendalam mengenai suatu objek penelitian tertentu yang sedang dikaji (Sofaer 1999). Penelitian kualitatif dimulai dengan pertanyaan penelitian yang kemudian akan menentukan metode pengumpulan data dan teknik menganalisis data. Secara empiris, prosedur penelitian yang dihasilkan berupa data deskriptif berupa kata-kata tertulis maupun lisan dari perilaku yang diamati (Moeleong 2005)

Sedangkan, menurut Sugiyono, deskriptif merupakan suatu tipe penelitian yang digunakan untuk menggambarkan dan menganalisis suatu hasil penelitian, namun tidak digunakan untuk membuat kesimpulan secara luas (idtesis t.t) Model penelitian deskriptif juga dapat diartikan sebagai penelitian yang menggambarkan suatu fenomena atau peristiwa yang diteliti secara apa adanya berdasarkan fakta-fakta, kejadian-kejadian secara sistematis dan akurat (Suharsimi 2002). Penelitian deskriptif hanya menjelaskan, menggambarkan, mengamati variabel-variabel dalam penelitian tanpa mengukur atau menguji hal tersebut (Shuttleworth t.t).

Sebagaimana umumnya, tahap-tahap yang ada dalam penelitian ini terdiri dari tahap persiapan yang diawali dengan memilih tema atau topik, menyusun pertanyaan penelitian, kemudian menyusun kerangka penelitian. Tahap pelaksanaan yang merupakan bagian inti dalam penelitian ini akan memasukan sub-tahap pengambilan data dengan metode wawancara dan studi pustaka, yaitu: dengan mewancarai Ibu Rita selaku staf Bagian Kerja Sama Luar Negeri, Pemerintah Kota Surabaya; dan juga mengumpulkan dokumendokumen, buku, jurnal, artikel dan berita daring maupun luring yang berkaitan dengan kerja sama Sister City Surabaya-Guangzhou. Tahap analisa data dalam penelitian ini menggunakan model analisis yang dikemukakan oleh Milles dan Huberman (2007) yang terdiri dari tiga alur kegiatan, yaitu: reduksi data, penyajian, data dan penarikan kesimpulan. 


\section{Analisis Kerja Sama Perkembangan Sister City Surabaya-Guangzhou}

\section{Realisasi Kerja Sama}

Dalam MoU kerja sama Sister City Surabaya-Guangzhou yang ditandatangani pada 21 Desember 2005, pemerintah kedua kota telah menyepakati sejumlah bidang kerja sama yang dikelompokkan ke dalam lima klaster, yaitu tata cara manajemen perkotaan; promosi usaha; perdagangan dan pariwisata; kebudayaan, kesenian, dan pendidikan; serta pemuda dan olahraga. Kelima bidang kerja sama tersebut kemudian direalisasikan dalam berbagai bentuk kegiatan bersama sebagaimana ditunjukkan dalam Tabel 1.

\section{Perkembangan dan Dampak}

Dari bidang-bidang kerja sama yang disepakati dalam MoU, tidak semua bidang kerja sama yang telah disepakati berjalan secara berkelanjutan. Beberapa di antaranya hanya berjalan beberapa kali saja, seperti bidang perdagangan yang hanya berjalan satu kali. Ada juga bidang kerja sama yang tidak berjalan sama sekali yaitu pendidikan. Selain itu ada juga bidang olahraga yang juga berjalan satu kali. Bidang pariwisata juga hanya berjalan satu kali. Sehingga, dari lima bidang kerja sama sister city yang disepakati, hanya beberapa bidang saja yang berjalan secara berkelanjutan, yaitu tata cara manajemen perkotaan, promosi usaha, dan kebudayaan (Kartika 2019).

Berdasarkan realisasi sejumlah bidang kerja sama tersebut, maka dapat diketahui perkembangan Sister City Surabaya-Guangzhou berserta dampaknya terhadap kota Surabaya, sebagaimana ditunjukkan dalam tabel 2. 


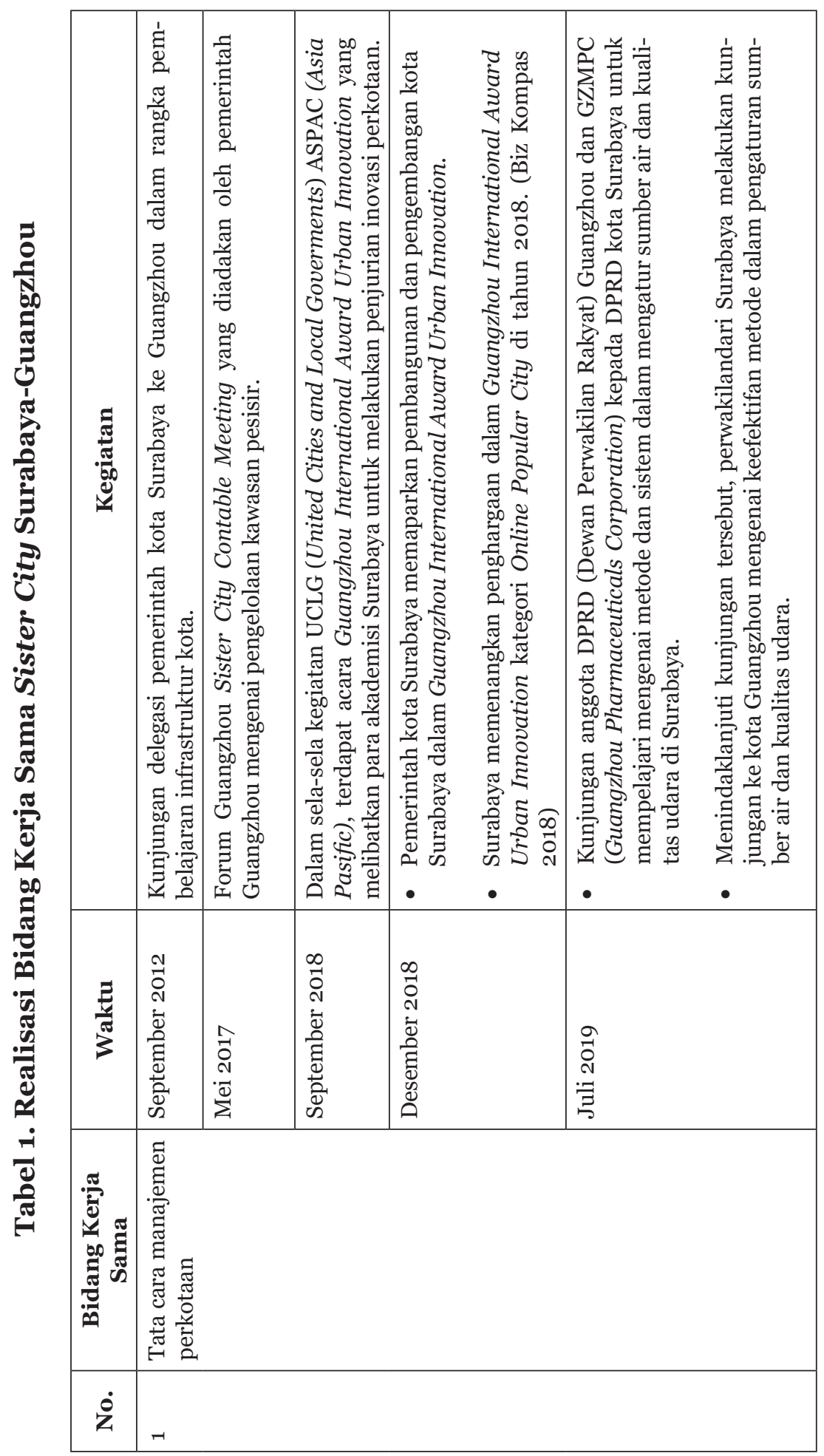




\begin{tabular}{|c|c|c|c|c|c|c|c|c|c|}
\hline 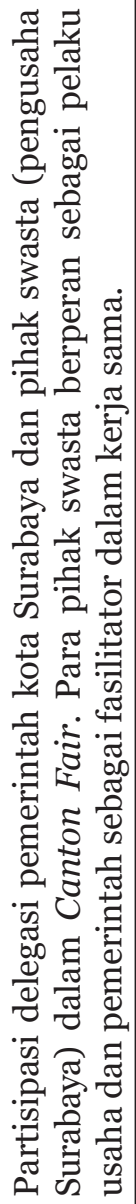 & 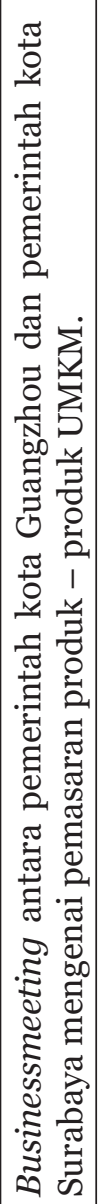 & 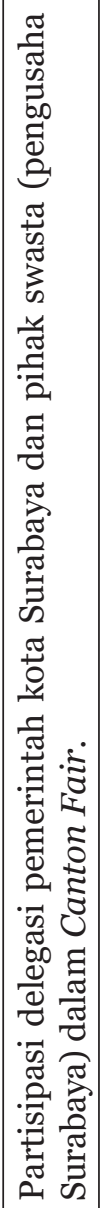 & 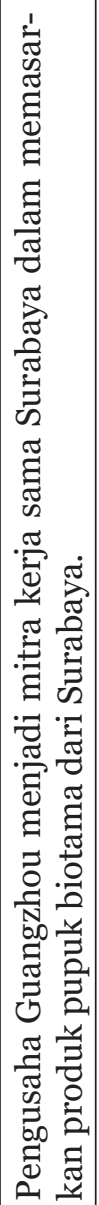 & 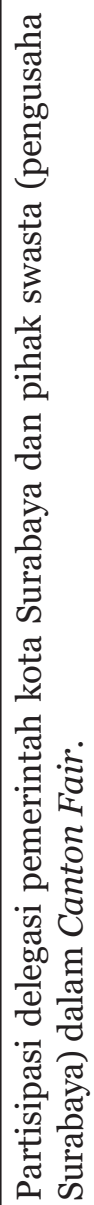 & 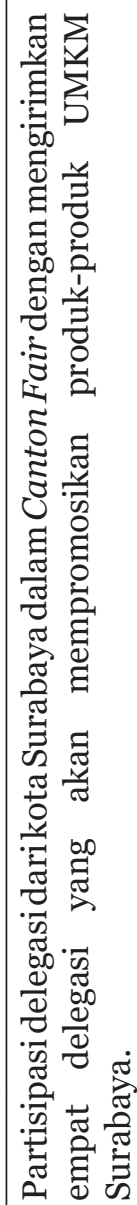 & 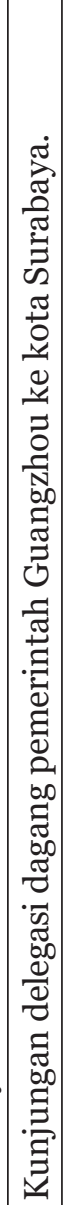 & 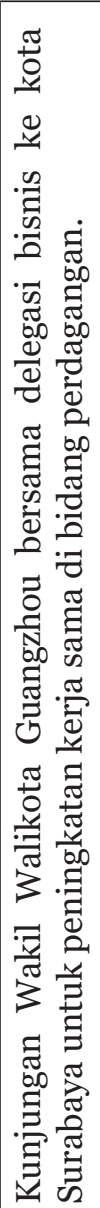 & 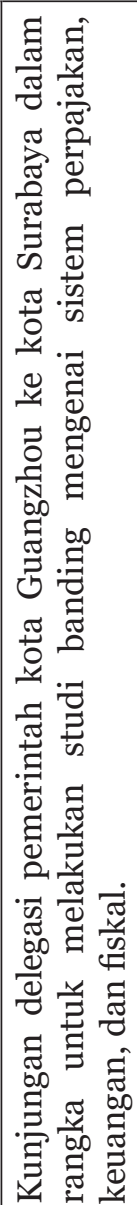 & 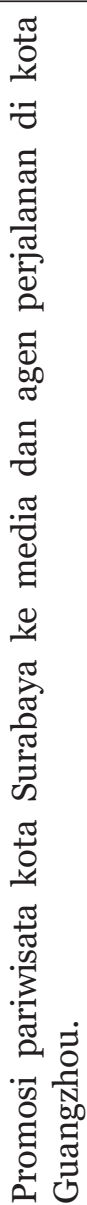 \\
\hline 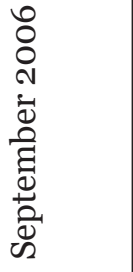 & 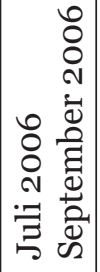 & 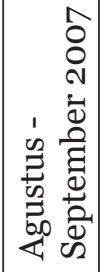 & 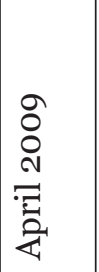 & 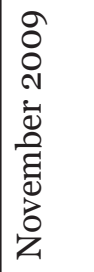 & 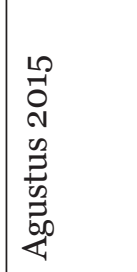 & 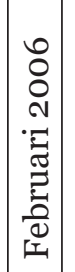 & 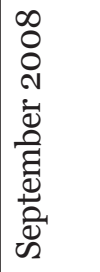 & 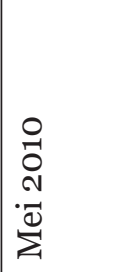 & 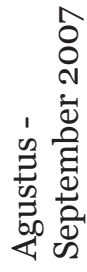 \\
\hline 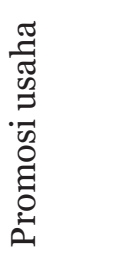 & & & & & & 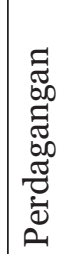 & & & 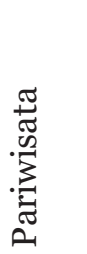 \\
\hline$N$ & & & & & & $\infty$ & & & \\
\hline
\end{tabular}




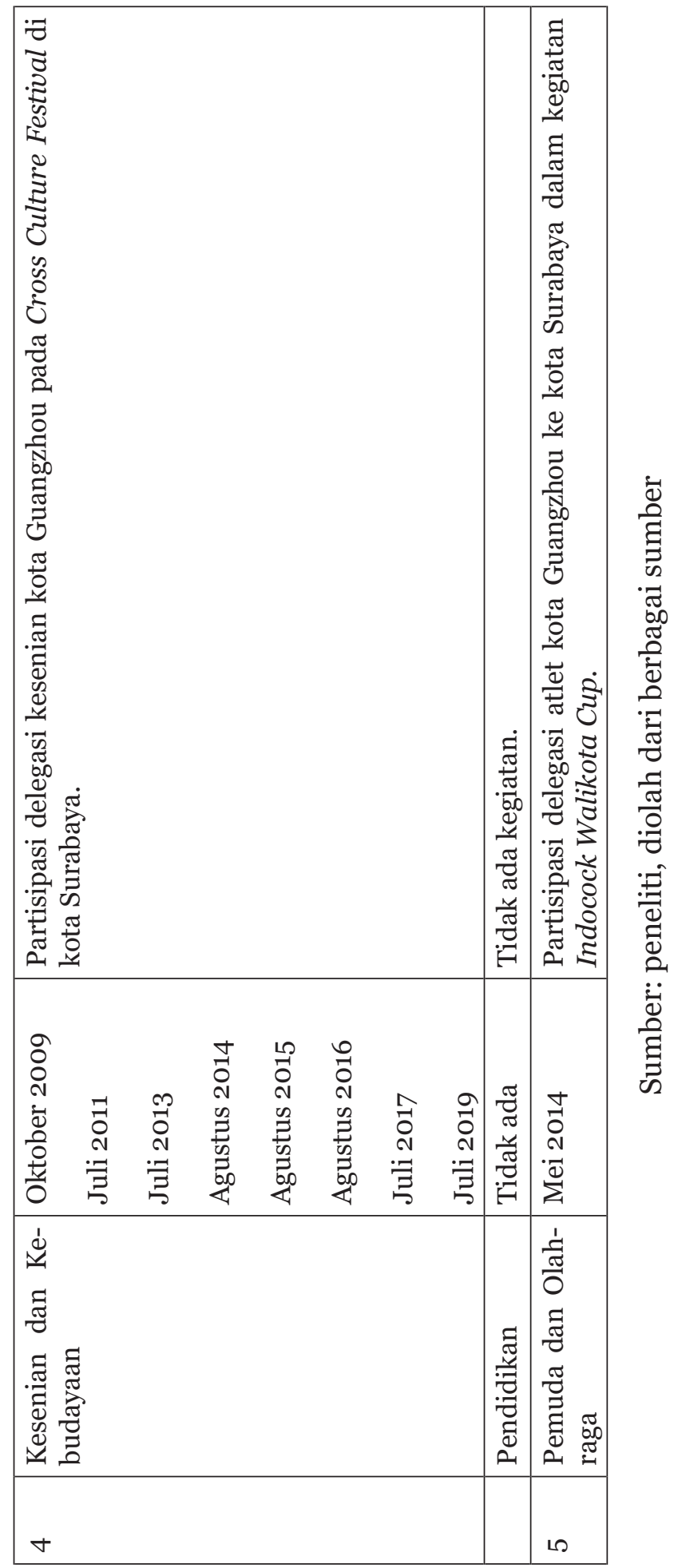




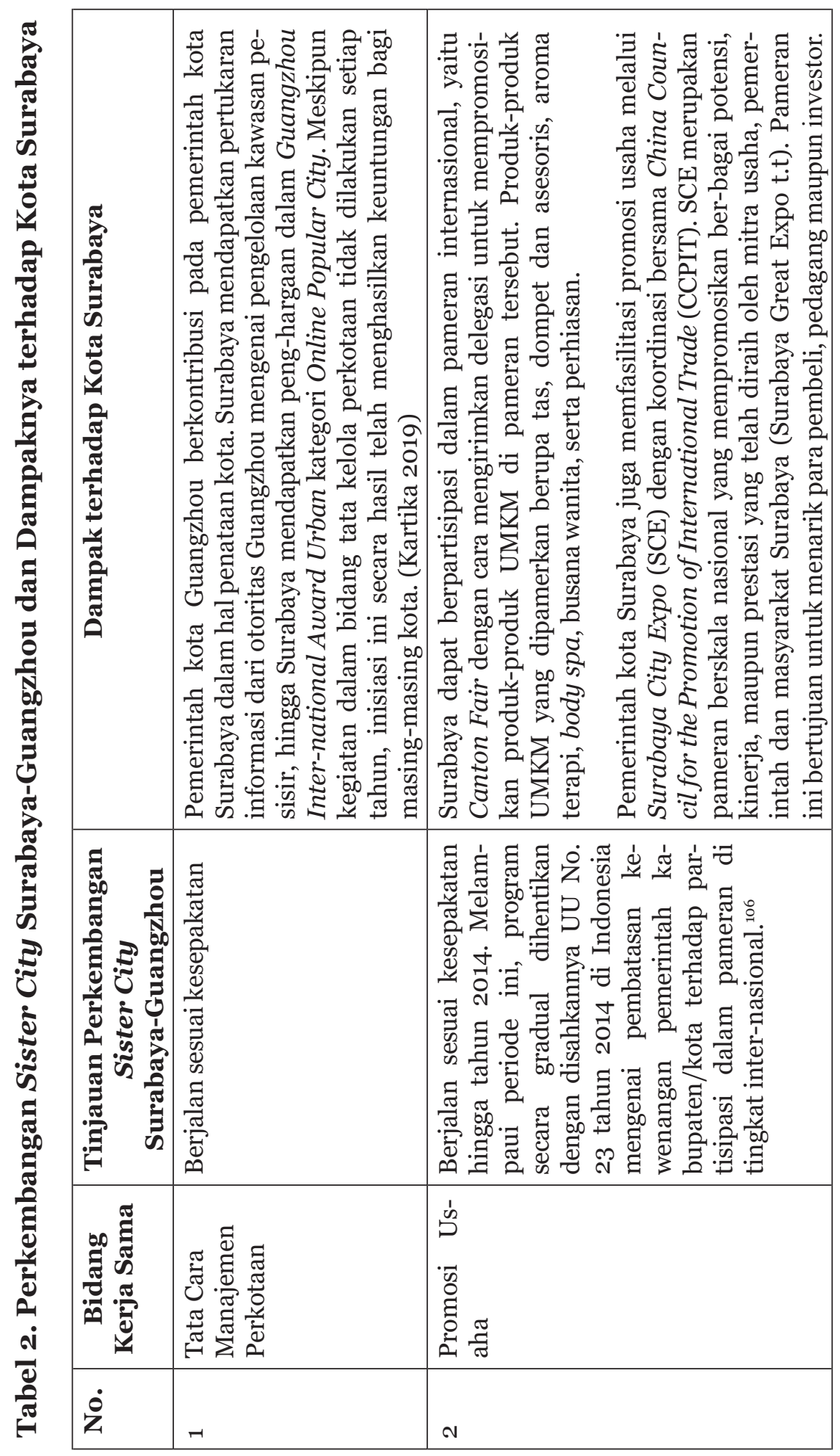




\begin{tabular}{|c|c|c|c|}
\hline 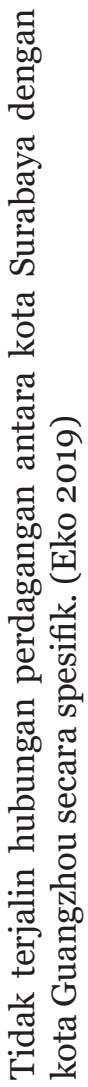 & 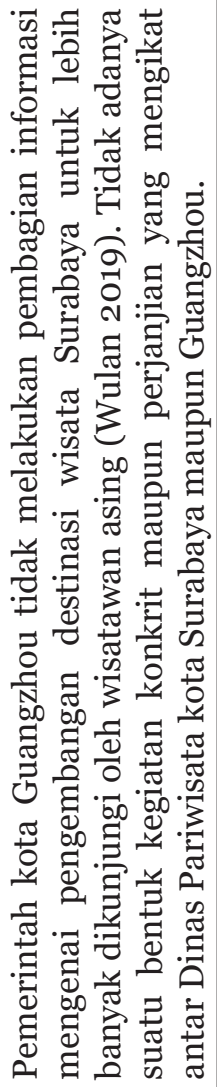 & 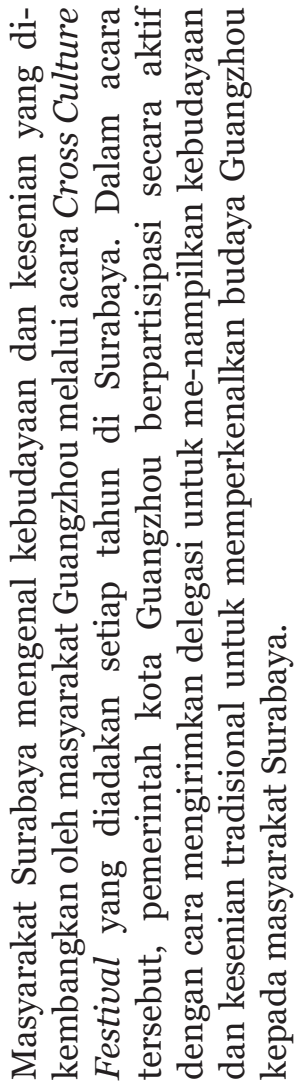 & 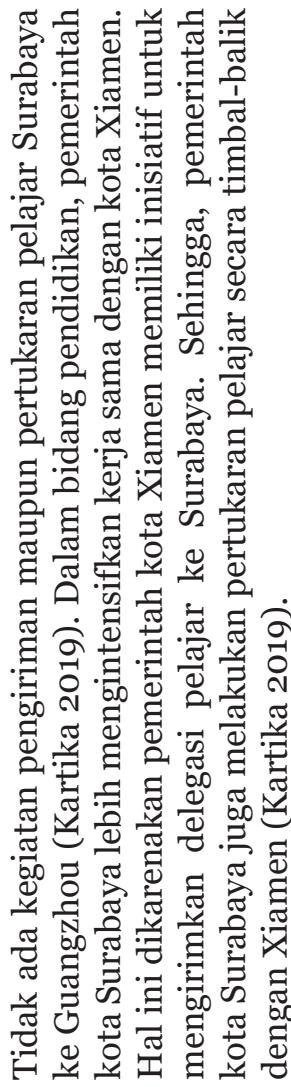 \\
\hline 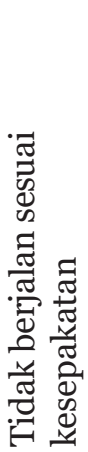 & 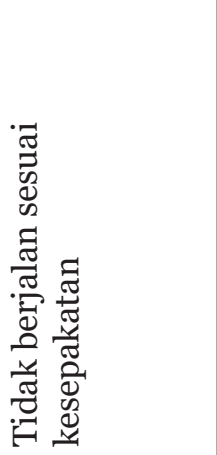 & 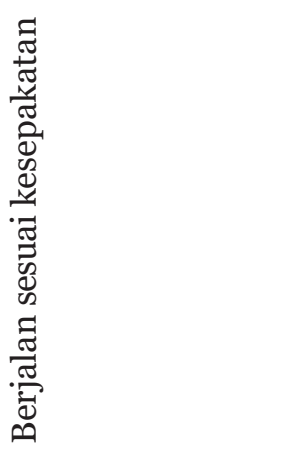 & 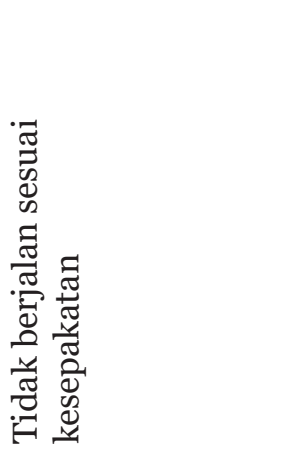 \\
\hline 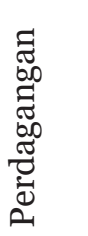 & . & 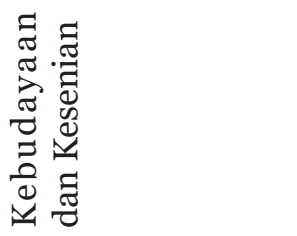 & 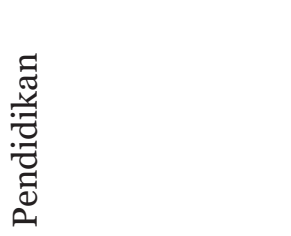 \\
\hline & & & \\
\hline
\end{tabular}




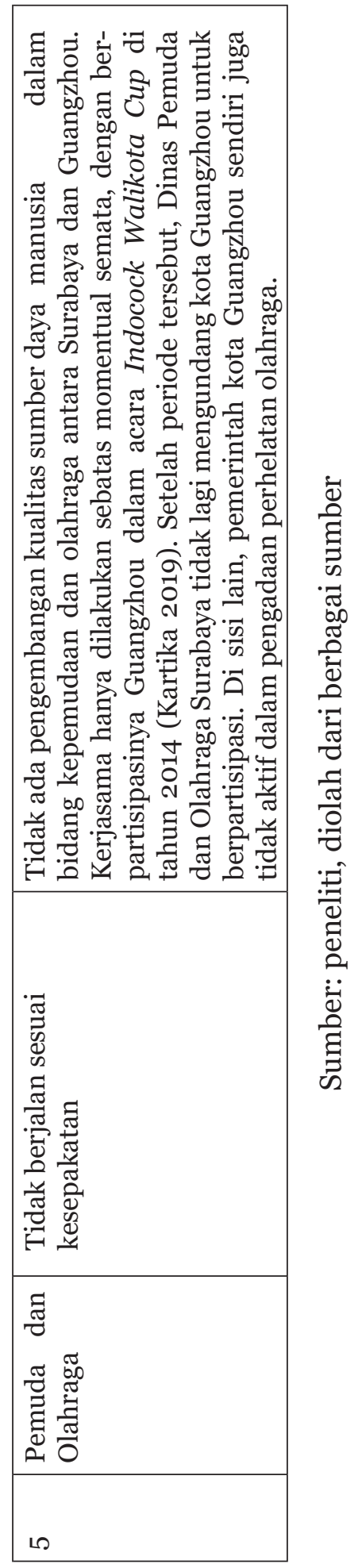




\section{Analisis Efektivitas dengan Teori Efektivitas Rezim}

Perkembangan kerja sama Sister City Surabaya-Guangzhou yang demikian ini lantas akan ditinjau dengan menggunakan teori efektivitas rezim yang dikembangkan oleh Arild Underdal. Efektif tidaknya bidang kerja sama sister city bukan diukur dari seberapa banyak kegiatan yang dilakukan setiap tahun, melainkan diukur dari tercapainya tujuan awal kesepakatan kerja sama dalam bidang tersebut. Underdal (2001) menilai bahwa keefektifan suatu rezim sejatinya diukur dari keberhasilan melakukan fungsinya dan dapat mencapai tujuan awal pembentukan rezim tersebut atau memecahkan permasalahan yang sedang dihadapi. Menurut Underdal (2001), terdapat tiga komponen sebagai variabel independen yang menentukan efektivitas rezim, yakni tingkat kaloborasi (Level of Colaboration), kegawatan persoalan (Problem Malignancy) dan kapasitas permasalahan (Problem Solving). Variabel-variabel tersebut diperiksa untuk mengetahui efektif atau tidaknya Sister City Surabaya-Guangzhou. Level of Collaboration akan diukur melalui output, outcome, dan impact sehingga akan menghasilkan skala ordinal.

Output didefinisikan sebagai kesepakatan yang dilakukan oleh kepala pemerintah kedua kota, yang dalam hal berupa LoI (Letter of Intent) yang dibuat antara pemerintah kota Surabaya dan kota Guangzhou pada 2 September 2003 dan juga MoU (Memorandum of Understanding) pada 21 Desember 2005. Outcome merupakan hasil dari implementasi program/rezim yang berhubungan dan berdampak pada perubahan perilaku aktor yang terlibat dalam rezim yang disepakati. Sehingga, outcome dalam konteks ini salah satunya adalah ketika Surabaya dapat membuat pameran yakni Surabaya City Expo yang dikoordinasi di bawah CCPIT (China Council for the Promotion of International Trade). Outcome di bidang tata cara manajemen perkotaan adalah ketika Surabaya menjadi satusatunya kota yang mewakili Asia Tenggara dalam Guangzhou International Award tahun 2018 (Puspa 2018). Surabaya berhasil mendapatkan penghargaan dalam Guangzhou International Award Urban kategori Online Popular City. Bahkan, setelah keberhasilan tersebut, Walikota Surabaya lebih intensif dan lebih memfokuskan pada penataan dan perencanaan kota (Humas Kota Surabaya 2018). Terakhir, outcome di bidang kebudayaan adalah ketika terjadi pertukaran budaya antara masyarakat Indonesia dan Tiongkok dengan hadirnya delegasi Guangzhou di Cross-Culture Festival di Surabaya. 
Impact merupakan keberhasilan dalam mengatasi permasalahan dalam pembentukan suatu rezim. Bidang kerja sama tata cara manajemen perkotaan dapat dikatakan telah mencapai tujuan yang tersemat dalam Sister City Surabaya-Guangzhou karena kedua kota mendapatkan pengetahuan secara mutual mengenai pembangunan gedung dengan tetap memprioritaskan aspek lingkungan seperti penyediaan ruang terbuka hijau. Bidang kerja sama promosi usaha juga mencapai tujuan karena dapat mempromosikan produkproduk UMKM surabaya dalam Canton Fair yang dilaksanakan oleh pemerintah Guangzhou setiap tahun. Bidang kerja sama perdagangan dan pariwisata tidak mencapai tujuan karena agenda yang telah dilakukan hanya sebatas pada pertemuan delegasi semata. Sementara itu, bidang pariwisata tidak dapat diukur karena $\mathrm{MoU}$ kerja sama antar kedua kota tersebut tidak mengandung spesifikasi tentang promosi pariwisata. Bidang kerja sama kebudayaan dan kesenian mencapai tujuan karena kota Surabaya memiliki acara Cross Culture Festival yang diadakan setiap tahun dan pemerintah kota Guangzhou selalu berpartisipasi secara aktif dalam acara tersebut. Bidang pendidikan tidak mencapai tujuan karena kegiatan peningkatan kualitas sumber daya manusia dengan cara pertukaran pelajar maupun tim pengajar ke kota Guangzhou maupun Surabaya belum dapat terrealisasikan. Bidang kerja sama pemuda dan olahraga tidak mencapai tujuan karena memang tidak ada kegiatan secara spesifik yang dilakukan secara periodik, serta pemerintah kota Guangzhou maupun pemerintah kota surabaya tidak mengadakan perhelatan olahraga dengan intensif (Kartika 2019; Eko 2019)

Berdasarkan pengukuran terhadap output, outcome dan impact di atas, maka tingkat kolaborasi Sister City Surabaya-Guangzhou tergolong bernilai dua dalam skala ordinal. Menurut Arild Underdal skala dua berarti bahwa para anggota rezim yang telah disekapati berkoordinasi dan bertindak berdasarkan aturan atau standar yang telah dirumuskan. Namun, dalam hal pelaksanaan, tidak ada penilaian secara terpusat terhadap efektivitas berjalannya rezim dan implementasi sepenuhnya diserahkan kepada tiap masingmasing pihak (Underdal 2001). Kondisi ini lantas mengindikasikan bahwa rezim Sister City Surabaya-Guangzhou berjalan dengan kurang efektif. Kerja sama sister city ini diatur dalam MoU yang telah disepakati. Namun, tidak ada standar pelaksanaan dalam menjalani bidang-bidang kerja sama yang dimaksud. MoU tersebut tidak mencantumkan mekanisme penilaian secara terpusat dari otoritas yang lebih tinggi, sehingga penilaian kerja sama sister city diserahkan kepada masing-masing pemerintah kota. Tidak ada 
aturan yang mengharuskan kedua pemerintahan, yakni Surabaya dan Guangzhou, untuk harus mengadakan kegiatan kerja sama di setiap bidang setiap tahun (Kartika 2019).

Sedangkan, jika dinilai dari aspek problem malignancy, efektivitas rezim ditentukan dari seberapa gawat permasalahan yang terjadi di dalam rezim. Semakin rumit permasalahan yang terjadi maka semakin rendah tingkat efektivitas rezim; demikian sulit terjadinya kooperasi. Kurang efektifnya rezim Sister City Surabaya-Guangzhou dapat dijelaskan dari kegawatan permasalahan (problem malignancy) yang bersifat incongruity: adanya perbedaan kesepahaman kepentingan antara pemerintah kota Surabaya dengan pemerintah kota Guangzhou. Hal ini ditunjukkan dengan adanya bidang-bidang kerja sama Sister City Surabaya-Guangzhou yang tidak mencapai tujuan. Pertama, bidang pendidikan karena perbedaan budaya pendidikan antara Surabaya dengan Guangzhou. Kedua, bidang pariwisata, karena tidak ada spesifikasi untuk melakukan kerja sama. Ketiga, bidang perdagangan karena kota Guangzhou lebih mengedepankan berdagang dengan kota di negara Eropa. Keempat, bidang pemuda dan olahraga karena pihak Dinas Olahraga Surabaya dengan KONI (Komite Olahraga Nasional Indonesia) tidak mengundang pemerintah kota Guangzhou untuk berpartisipasi dalam event-event olahraga dan juga adanya perbedaan kompetensi atlet kota Surabaya yang berbeda dengan atlet yang dimiliki kota Guangzhou.

Problem solving capacity merupakan kapasitas yang dimiliki oleh rezim untuk memunculkan solusi dalam menyelesaikan masalah seputar implementasi. Kurang efektifnya rezim sister city SurabayaGuangzhou juga disebabkan oleh pergantian kepala pemerintah masing-masing kota. Pergantian kepala pemerintah kota Surabaya adalah dari Bambang D.H ke Tri Rismaharini. Sedangkan pergantian kepala pemerintah kota Guangzhou adalah dari Zhang Guangning ke Wen Guohui. Pergantian kepala pemerintah kedua kota tersebut berdampak pada pergeseran skill dan energy yang menyebabkan perbedaan kebijakan dalam menyikapi kerja sama sister city. Tri Rismaharini lebih berfokus pada masalah lingkungan, sehingga mengutamakan kerja sama sister city Surabaya dengan Kitakyushu yang secara kesepakatan memiliki prominensi kerja sama dalam bidang tersebut. Sementara itu, Wen Guohui memiliki fokus lain pada kerja sama sister city Guangzhou dengan kota-kota di Eropa. Ketika terjadi pergantian tongkat kepemimpinan di kedua kota tersebut, tidak ada solusi yang diberikan kepada kepengurusan 
berikutnya berupa sinkronisasi kebijakan dalam menyikapi inisiasi sister city yang telah disepakati di awal.

\section{Kesimpulan}

Dalam perkembangannya, tulisan ini telah menunjukkan bahwa kerja sama Sister City Surabaya-Guangzhou dapat dikatakan telah berjalan dengan kurang efektif. Pertama, indikator level of collaboration menunjukkan skala dua bagi inisiasi ini, Lantas, hal ini berarti bahwa rezim sister city tersebut memiliki tingkat kolaborasi dan tingkat kepatuhan yang cukup minim. Kerja sama sister city antara pemerintah kota Surabaya dengan pemerintah kota Guangzhou diatur dalam MoU yang telah disepakati. Namun, tidak ada standar pelaksanaan dalam menjalani bidang-bidang kerja sama yang telah disepakati. Kedua, aspek problem malignancy menunjukan bahwa rezim tersebut memiliki masalah yang bersifat incongruity, yaitu perbedaan kesepahaman kepentingan antara pemerintah kota Surabaya dengan pemerintah kota Guangzhou. Dalam bidang kerja sama Sister City Surabaya-Guangzhou, terdapat beberapa bidang yang tidak mencapai tujuan awal kesepakatan. Ketiga, segi problem solving capacity menunjukkan bahwa rezim sister city tersebut tidak dapat menemukan solusi untuk keberlanjutan program dikarenakan terjadi pergantian kepala pemerintahan di kedua kota. Hal ini berimbas pada kurang sinkronnya kebijakan pemerintah kota sebelumnya kepada penerusnya dalam menyikapi Sister City Surabaya-Guangzhou agar berjalan sesuai dengan tujuan awal kesepakatan. Kurang efektifnya Sister City SurabayaGuangzhou berakibat pada dampak yang didapatkan oleh kota Surabaya. Meskipun tidak berjalan maksimal, dampak Sister City Surabaya-Guangzhou terhadap kota Surabaya tetap dirasakan pada beberapa bidang kerja sama yang disepakati, seperti bidang tata cara manajemen perkotaan, promosi usaha, serta kesenian dan kebudayaan. Sementara bidang perdagangan, pariwisata, pendidikan, serta pemuda dan olahraga tidak mendapatkan implikasi yang signifikan. 


\section{Daftar Pustaka}

\section{Buku}

Majid, Mohammed Z.M Abdul \& Ahmad N. 2010. "Tapping new possibility in accounting research", dalam qualitative research in accounting: Malaysian case. Kuala Lumpur: University Kebangsaan Malaysia.

Milles dan Huberman. 2007. Analisis Data Kualitatif. Jakarta: Unirversitas Indonesia Press.

Moleong, Lexy. 1994. Metode Penelitian Kualitatif. Jakarta: Rosda Karya.

. 2005. Metode Penelitian Kualitatif. Bandung: Remaja Rosdakarya.

Suharsimi, Arikunto. 2002. Prosedur Penelitian: Suatu Pendekatan Praktek. Jakarta: PT Rineka Cipta.

Sukmadinata, N.S. 2011. Metode Penelitian Pendidikan. Bandung: Remaja Rosadakarya.

Sulistyo, Basuki. 2006. Metode Penelitian. Jakarta: Wedatama Widya Sastra dan Fakultas Ilmu Pengetahuan Budaya Universitas Indonesia.

\section{Skripsi}

Ariana, Dina. 2016. Keuntungan Kerja sama Sister City antara Kota Surabaya dengan Xiamen Tiongkok. Skripsi Sarjana. Yogyakarta: Universitas Gadjah Mada.

Bramantio, Rio Rakhmat. 2008. Efektivitas Kerja sama Sister City Surabaya dengan Busan dan Surabaya dengan Kochi Dalam Bidang Pendidikan. Skripsi Sarjana. Surabaya: Universitas Airlangga.

Kilinggoru, Rambu Norlin.2018. Implementasi Kerja sama Green Sister City antara Pemerintah Kota Surabaya dengan Pemerintah Kota Kitakyushu-Jepang pada Tahun 2012-2015. Skripsi Sarjana. Surabaya: Universitas Pembangunan Nasional Veteran. 
Sauwir, Rizky Pradipta. 2013. Efektivitas Implementasi Pemerintah Surabaya Melaksanakan Kerja sama Sister City dengan Busan (2007-2012) di bidang pendidikan. Skripsi Sarjana. Surabaya: Universitas Pembangunan Nasional Veteran.

\section{Artikel Jurnal}

Clarke, Nick. 2011. "Globalising care? Town twinning in Britain since 1945”, Jurnal Geoforum, 42(1) [PDF]. Tersedia dalam https:// eprints.soton.ac.uk/169119/1/Globalising_care_FAVPPR.pdf (diakses 26 November 2019).

Irdayanti, I. 2014. "Substansi Kerja sama Luar Negeri Sister City Kota Surabaya - Xiamen tahun 2014”, Khutubkhanah, 17(1).

Salam, Usmar. 2004. "Dinamika Kerja sama Internasional Provinsi di Indonesia dengan Luar Negeri”, Makalah Lokakarya Cara penanganan Kerja sama Internasional, 7.

Sofaer, S. 1999. "Qualitative methods: what are they and why use them?”, Health Services, 34(4).

Srivastava, A. \& Thomson S.B. 2009. "Framework analysis: a qualitative methodology for applied policy research". JOAAG, 4(2).

Underdal, Arild. 2001."One Question Two Answer" dalam Edward L. Miles. et. al. (ed.) Environmental Regime Effectiveness: Confronting Theory with Evidence. Cambridge: MIT press.

\section{Artikel dan Situs Resmi}

Humas Kota Surabaya. 2018. "Pulang Dari Guangzhou China, Wali Kota Risma Semakin Intensif Menata Surabaya” [daring] tersedia dalam https://humas.surabaya.go.id/2018/12/18/pulang-dari-guangzhouchina-wali-kota-risma-semakin-intensif-menata-surabaya/ (diakses pada 18 Desember 2019).

Memorandum of Understanding (MOU) Sister City SurabayaGuangzhou, 2005. Surabaya: Pemerintah Kota Surabaya.

Oklahoma Secretary of State. "Sister States/Cities" [daring]. Tersedia 
dalam https://www.sos.ok.gov/protocol/sisterStates.aspx (diakses 17 Desember 2019).

Pemerintah Kota Surabaya, t.ta. [daring]. Tersedia dalam https:// surabaya.go.id/ (diakses 17 Oktober 2019).

, t.tb. "Sister City" [daring]. Tersedia

dalam http://www.surabaya.go.id/sistercity/ (diakses 22 November 2019).

Tersedia dalam https://surabaya.go.id/id/page/o/8177/ sosial-ekonomi (diakses 17 Desember 2019)

Sister-city, t.t. [daring]. Tersedia dalam https://sistercities.org/ (diakses 17 Oktober 2019).

Surabaya Great Expo. t.t [daring]. Tersedia dalam http:// surabayagreatexpo.com/_(diakses 26 November 2019).

\section{Wawancara}

Eko. 2019. Wawancara dengan penulis pada tanggal 6 Desember 2019. Surabaya: Kantor Dinas Perdagangan Surabaya .

Kartika, Rita. 2019. Wawancara dengan penulis pada tanggal 7 Oktober, 25 November, 3 Desember, 22 November, 5 Desember 2019. Surabaya: Kantor Bagian Administrasi Kerja Sama Pemerintah Kota Surabaya .

Rino, 2019. Wawancara dengan penulis pada tanggal 3 Desember 2019. Surabaya: Kantor Dinas Kebudayaan Dan Pariwisata Kota Surabaya.

Wulan, 2019. Wawancara dengan penulis pada tanggal 3 Desember 2019. Surabaya: Kantor Dinas Kebudayaan dan Pariwisata Surabaya.

\section{Artikel dan Situs Daring}

Biz Kompas, t.t "Raih Online Popular City Guangzhou International Award 2018 Bukti Nyata Partisipasi Publik" [daring]. Tersedia 
dalamhttps://biz.kompas.com/read/2018/12/12/144124428/ raih-online-popular-city-guangzhou-international-award2018-bukti-nyata (diakses 26 November 2019).

East Java. "Tentang Kota Surabaya” [daring]. Tersedia dalam https:// www.eastjava.com/tourism/surabaya/ina/about.html (diakses 17 Oktober 2019).

idtesis, t.t. "Definisi Metode Deskriptif" [daring]. Tersedia dalam https://idtesis.com/metode-deskriptif/ (diakses 1 November 2019).

Oetomo, Andi. 2004. "Pengelolaan Perkotaan Lewat Skema Sister City" [daring]. Tersedia dalam bulletin.penataanruang.net/ upload/data.../edisi3i.pdf (diakses 2 Oktober 2019).

Puspa, Wanti, 2018. "Wah! Surabaya Masuk 15 Besar Guangzhou International Award", CNBC Indonesia [daring]. Tersedia dalam https://www.cnbcindonesia.com/ news/20181130153258-4-44464/wah-surabaya-masuk-15besar-guangzhou-international-award (diakses 18 Desember 2019).

Shuttleworth, Martyn. t.t. "Descriptive Research Design" [daring]. https://explorable.com/descriptive-research-design (diakses pada 1 November 2019).

Sister-cities, t.t. "What Is a Sister City?”, Sister Cities International [daring]. Tersedia dalam http://sister-cities.org/what-sistercity (diakses_1 November 2019). 